\title{
A new genus and species of ctenid spiders (Aranei: Ctenidae) from South China
}

\author{
Новый род и виА пауков-ктенид (Aranei: Ctenidae) \\ из южкного Китая
}

\author{
Yuri M. Marusik ${ }^{1,2}$, Feng Zhang ${ }^{3}$ \& Mikhail M. Omelko ${ }^{2,4,5}$ \\ Ю.М. Марусик ${ }^{1,2}$, Ф. ЖКань ${ }^{3}$, М.М. Омелько

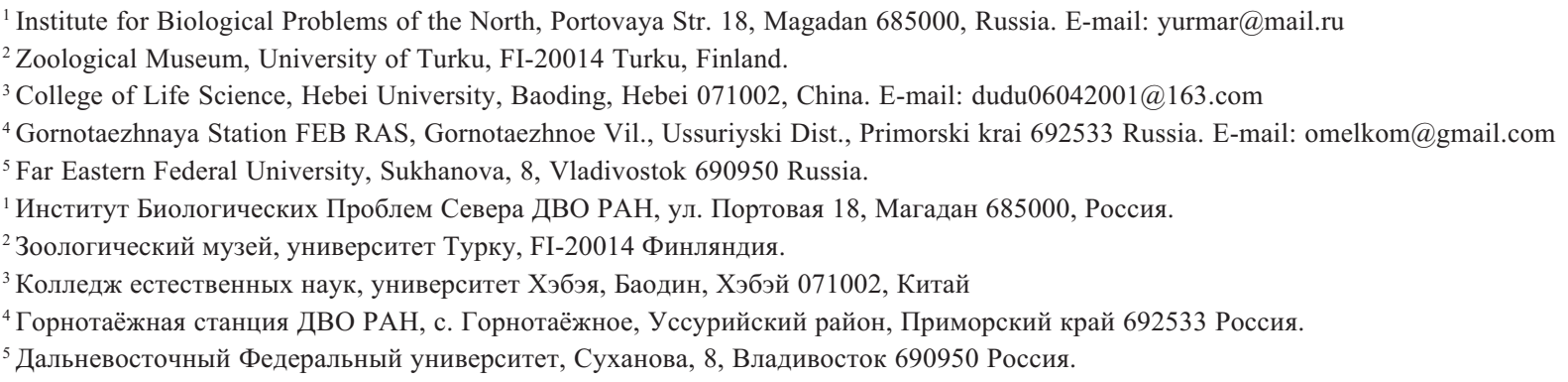

KEY WORDS: Sinoctenus zhui, new genus, new species, Ctenidae, China. КЛЮЧЕВЫЕ СЛОВА: Sinoctenus zhui, новый род, новый вид, Ctenidae, Китай.

ABSTRACT. Sinoctenus zhui gen.n., sp.n., belonging to Cteninae is described on the basis of three males from tropical forests in Hainan Island, southern China. Males have extraordinary long palps which are longer than the body, unusually shaped cymbium, a very large median apophysis covering almost the whole bulbus. Additionally, Sinoctenus gen.n. can be distinguished from other well-described ctenid genera by having a ridge on the retromargin of the chelicerae, just behind the teeth, and an elongate apical segment of posterior lateral spinnerets.

РЕЗЮМЕ. Sinoctenus zhui gen.n., sp.n. относящийся к Cteninae, описан по трем самцам из джунглей о-ва Хайнань, южный Китай. Самцы имеют чрезвычайно длинные, длиннее тела, пальпы с цимбиумом необычной формы и очень крупным, почти полностью закрывающем бульбус, медиальным отростком. Помимо этого, Sinoctenus gen.n. отличается от других хорошо описанных родов ктенид наличием гребня на задней части хелицер сразу за зубцами, а также удлиненным апикальным сегментом задних боковых паутинных бородавок.

\section{Introduction}

Ctenidae ranks 18 th out of 110 currently recognized extant spider families. It is chiefly a tropical family with 476 species assigned to 40 genera [Platnick, 2011]. Currently, at least five subfamilies are recognized in this family [Silva, 2003]. Ctenidae is a rather poorly studied family, especially in Asia. Most of the descriptive papers and revisions were published between late $19^{\text {th }}$ and early $20^{\text {th }}$ centuries; to date, the most recent work on Asian ctenids is a revision of ctenid spiders from India [Gravely, 1931]. In China this family appears to be poorly represented. Only three species belonging to Anahita Karsch, 1879, and one species provisionally placed in Leptoctenus L. Koch, 1878, are known so far [cf. Platnick, 2011].

While studying material from southern China we found three male specimens with remarkably long palps, clearly members of Ctenidae. However, we were unable to identify these specimens to species level and were not even able to place them in any known genus. After studying the relevant literature and comparing the characters of our specimens with the matrix made by Silva [2003] we came to the conclusion that we have a new species belonging to a new genus. Therefore, the goal of this paper is to provide a detailed illustrated description of this new taxon.

\section{Material and methods}

Specimens were photographed using an Olympus Camedia E-520 camera attached to an Olympus SZX16 stereomicroscope at the Zoological Museum, University of Turku.

Photographs were taken in dishes with paraffin on the bottom. Different size holes were made in the 


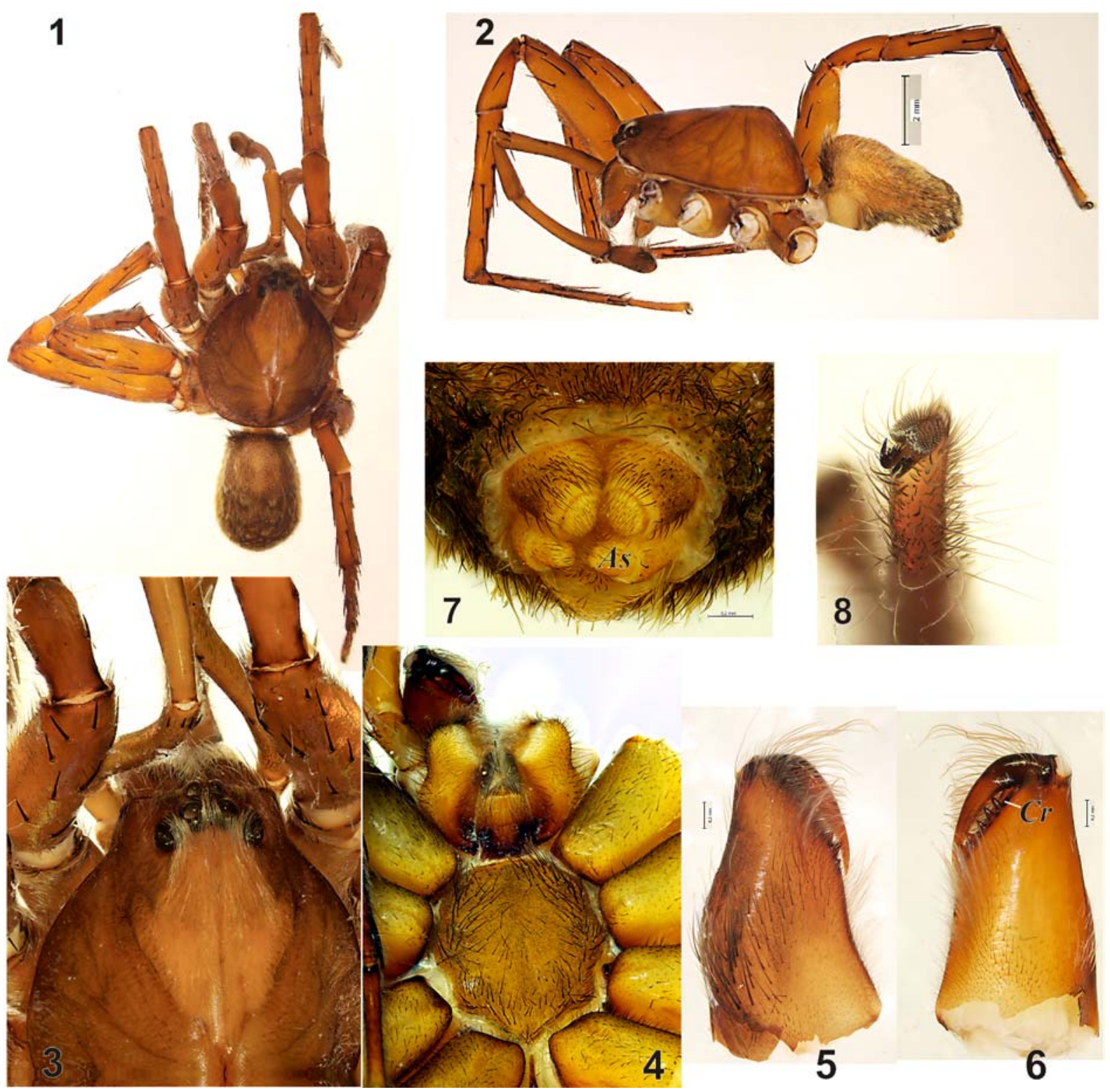

Figs 1-8. Somatic characters of Sinoctenus zhui sp.n.: 1-2 - body, dorsal and lateral, respectively; 3 - prosoma, dorsal; $4-$ prosoma, ventral; 5-6 - chelicera, frontal and inner view respectively; 7 - spinnerets; 8 - tarsus III showing dense claw tufts, apical.

Abbreviations: $\mathrm{As}$ - apical segment of posterior lateral spinnerets, $\mathrm{Cr}$ - cheliceral ridge.

Рис. 1-8. Соматические признаки Sinoctenus zhui sp.n.: 1-2 - тело, дорзально и латерально, соответственно; 3 - головогрудь, дорзально; 4 - головогрудь, вентрально; 5-6 - хелицера, спередни и изнутри, соответственно; 7 - паутинные бородавки, 8 - лапка III с густой коготковой подушечкой, апикально.

Сокращения: $A s$ - апикальный сегмент задних боковых бородавок, $\mathrm{Cr}$ - гребень хелицеры.

paraffin to keep the specimens in the correct position. All specimens were collected by beating of the branches in rain forests.

The type specimens are deposited in the College of Life Science, Hebei University, Baoding (HBU) and Zoological Museum of the Moscow State University (ZMMU).

All measurements are in $\mathrm{mm}$.

\section{Taxonomic description}

\section{Sinoctenus gen.n.}

Type species: Sinoctenus zhui sp.n.

ETYMOLOGY. The generic name is composed from two words: Sina meaning China in Latin and Ctenus. The gender is masculine 


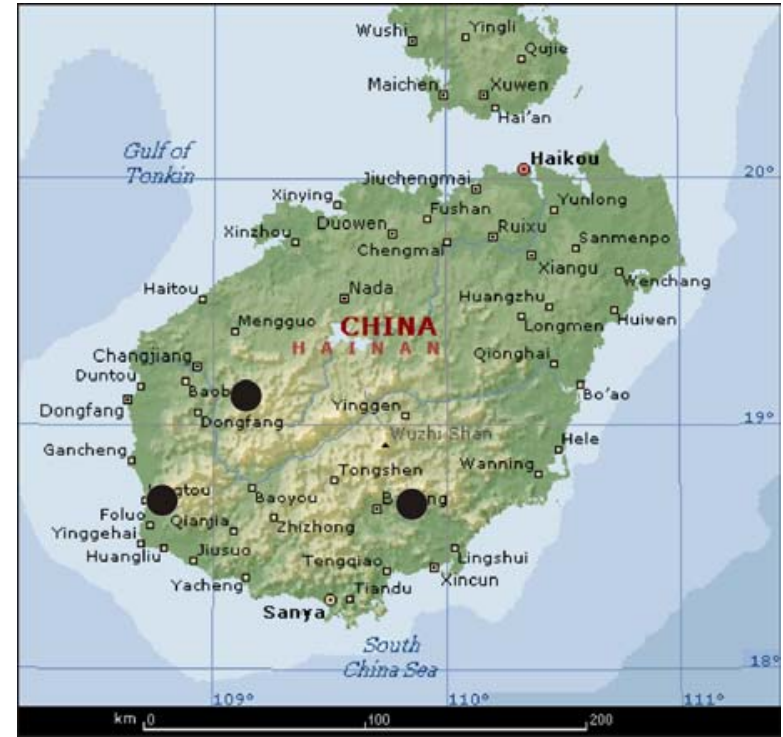

Map 1. Collecting localities of Sinoctenus zhui sp.n.

Карта 1. Места сборов Sinoctenus zhui sp.n.

DIAGNOSIS. Sinoctenus gen.n. differs from all other ctenid genera by having a male palp longer than body (Fig. 2), small spine-like tibial apophysis (cf. Fig. $11,13)$, shape of the cymbium broadest at its apical $1 / 3$ (cf. Fig. 20), and large median apophysis covering almost whole bulbus (Fig. 9). In addition to the characters of the male palp, males can be distinguished from other well described ctenid spiders by having a fine ridge on the retromargin of the chelicerae, just behind the teeth (Fig. 6) and an elongate apical segment of posterior lateral spinnerets (Fig. 7).

DESCRIPTION. Same as for species.

COMMENTS. According to somatic characters such as domed carapace, very low clypeus, eyes arrangement, cheliceral indentation, number of tarsal claws the new genus belongs to Cteninae. Nevertheless the new species does not belong to Ctenus Walckenaer, 1805. In the most recent revision [Brescovit \& Simó, 2007], this genus was diagnosed in the following way: "... Ctenus differ from other ctenine genera by the combination of the following characters: males have a short palpal tibia, tegulum elongated basally, embolus with a basal projection, and median apophysis short and truncated at the apex; females ...". In Sinoctenus gen.n. the palpal tibia is almost as long as the femur, and the median apophysis is large and almost round (cf. Fig. 9 ). Both genera have a basal embolic projection $(B p)$ (an interlocking lobe that fits in the subtegular notch), but in Ctenus it is very large, and in new genus it is very small. In the length of the palpal tibia the new genus resembles the Neotropical Centroctenus MelloLeitão, 1929 [cf. Brescovit, 1996]. Its members have a palpal tibia 1.5-2 times longer than the cymbium, but unlike the new genus, their cymbiums are of normal shape. The tibia has a relatively large RTA, has no crown of strong setae on the top, the median apophysis is of normal size and does not hide the embolus (cf. Brescovit, 1996: Fig. 29).
Additionally, Ctenus s.str. (Neotropical species closely related to the generotype) often have a modified metatarsus IV which is slightly curved and bears strong, fine spines. Such modification is absent in the new genus and in species from Asia considered to belong in Ctenus.

Potentially, members of the new genus may have been already described in Ctenus and known from female or juvenile specimens. According to Platnick's [2011] Catalog, 20 species from India and Southeast Asia are known either from females or juveniles. Almost all of these species are known from old original descriptions.

Certain similarities of Sinoctenus zhui sp.n. can be observed with Ctenus cf. javanus Pocock, 1897, and $C$. maculisternis Strand, 1909 (Bolivia and Brazil) (cf. Figs 20a-b in Silva, 2003). Both have a rather large median apophysis, and $C$. maculisternis has a similar shape and position of the embolus.

It would appear that Sinoctenus gen.n. is the only genus within Cteninae which has an elongate apical segment of the posterior spinnerets. The significance of this observation will require further examination of both male and female specimens.

\section{Sinoctenus zhui sp.n.}

Figs 1-22, Map 1.

MATERIAL. Holotype $\sigma^{\top}$ (HBU) China: Hainan, Diaoluoshan National Natural Reserve (E 10952', N 1843'), 5 June 2009 (Sheng-Tao Guo). Paratypes: $1 \sigma^{\top}$ (HBU) China: Hainan, Ledong County, Jianfengling Mountain (E 108 48', N 18 $42^{\prime}$ ), 31 May 2009 (Chao Zhang); $1 \sigma^{7}$ (ZMMU), China: Hainan, Changjiang County, Bawangling Town, Exianling Mountain (E 10908', N $\left.19^{\circ} 07^{\prime}\right), 20$ May 2009 (Chao Zhang). All specimens were collected by beating of the branches in rain forests.

ETYMOLOGY. The specific name is a patronym in honor of Prof. Mingsheng Zhu, a prominent arachnologist in China.

DIAGNOSIS. Same as for genus.

DESCRIPTION. Measurements. Total length 8.969.3. Carapace 5.1-5.3 long, 3.92-4.5 wide, 2.5 high, fovea 1.5 long. Clypeus near AME 0.07, near ALE 0.36, AME 0.24, ALE 0.16, PME 0.33, PLE 0.24. AME-AME 0.12, AME-ALE 0.28, PME-PME 0.18, PME-PLE 0.29. MOA length 0.47 with front width 0.51 and back width 0.73 . Thoracic fovea slit-like long (1/3 of carapace width).

Carapace and abdomen brown with poorly developed pattern (Figs 1-2). Carapace (Fig. 3) with diamond shaped light brown area (behind ocular area terminating near frontal edge of fovea) median light band around fovea; wide dark lateral bands with poorly developed submarginal light spots. Abdomen with light median band and darker heart mark. Sternum (Fig. 4) uniformly colored. Carapace domed, its highest point coinciding with middle part of fovea (Figs 2-3). Chelicera with 3 pro- and 4 retromarginal teeth, retromarginal side with a small ridge $(\mathrm{Cr})$ behind teeth (Figs 56). Chelicerae, maxillae, labium, sternum and legs brown. Legs with numerous spines. Tibia I with 5 pairs 


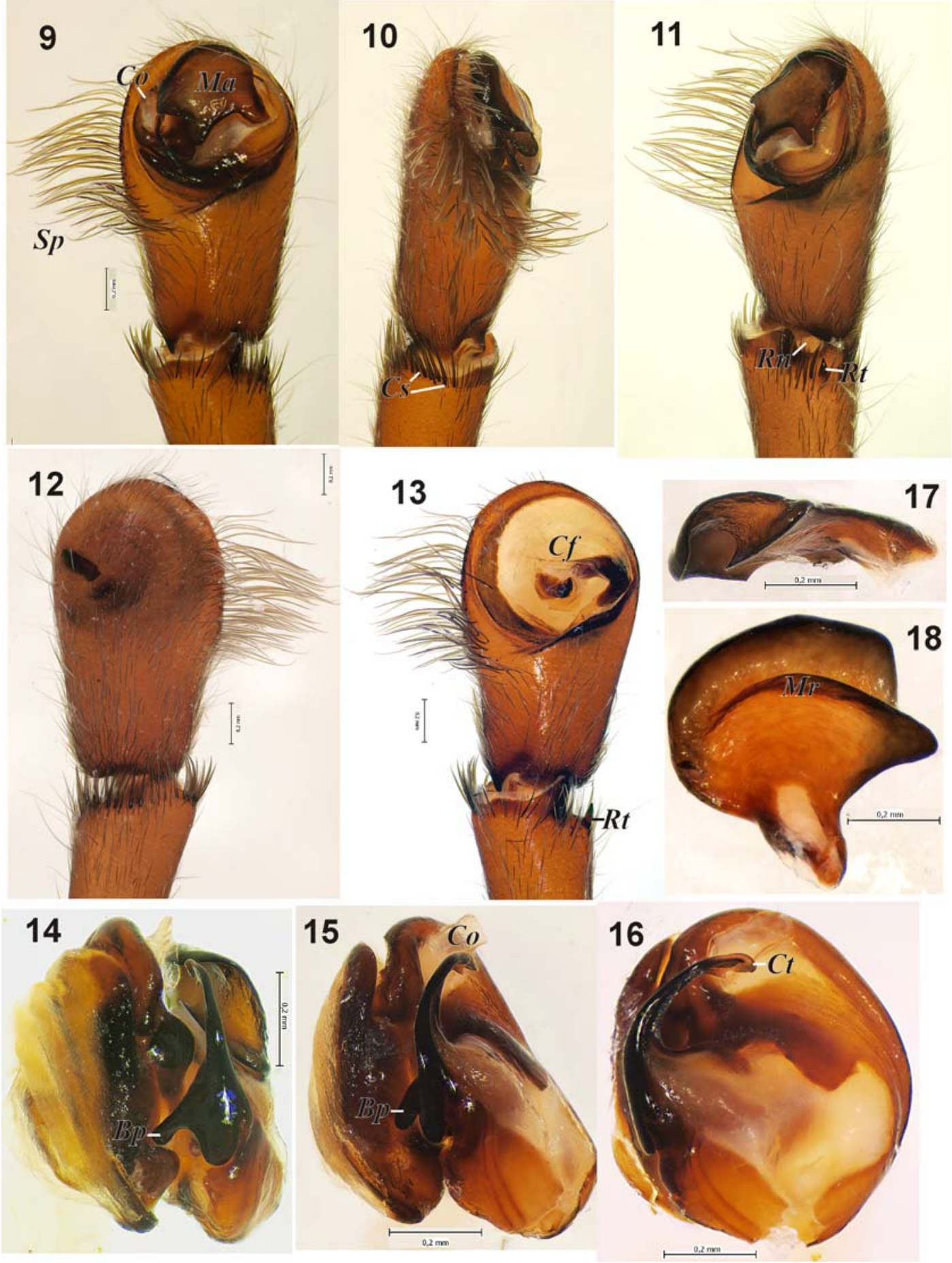

Figs 9-18. Male palp of Sinoctenus zhui sp.n.: 9-12 - terminal part, ventral, prolateral, retrolateral and dorsal respectively; $13-$ cymbium with removed bulbus; $14-16$ — bulbus, prolateral, ventro-prolateral and ventral respectively; $17-18$ — median apophysis, prolateral and dorsal respectively.

Abbreviations: $B p$ - basal process of embolus, $C f$ - cymbial fovea, $C o$ - conductor, $C s-$ crown of spines and setae, $C t-$ complex tip of embolus, $M a$ - median apophysis, $M r$ - inner ridge of the median apophysis, $R n$ - retrolateral notch of the palpal tibia, $R t-$ retrolateral tibial apophysis, $S p$-long protruding setae.

Рис. 9-18. Пальпа самца Sinoctenus zhui sp.n.: 9-12 - терминальная часть, вентрально, пролатерально, ретролатерально и дорзально, соответственно; 13 - цимбиум без бульбуса; 14-16 - бульбус, пролатерально, вентро-пролатерально и вентрально, соответственно; 17-18 - медиальный отросток, пролатерально и дорзально, соответственно.

Сокращения: $B p-$ базальный отросток эмболюса, $C f-$ ямка цимбиума, $C o-$ кондуктор, $C s-$ венец шипов и щетинок, $C t-$ сложный конец эмболюса, $M a$ — медиальный отросток, $M r$ — внутренний гребень медиального отростка, $R n$ - ретролатеральная выемка голени пальпы, $R t$ - ретролатеральный отросток пальпы, $S p$-длинные выдающиеся волоски. 


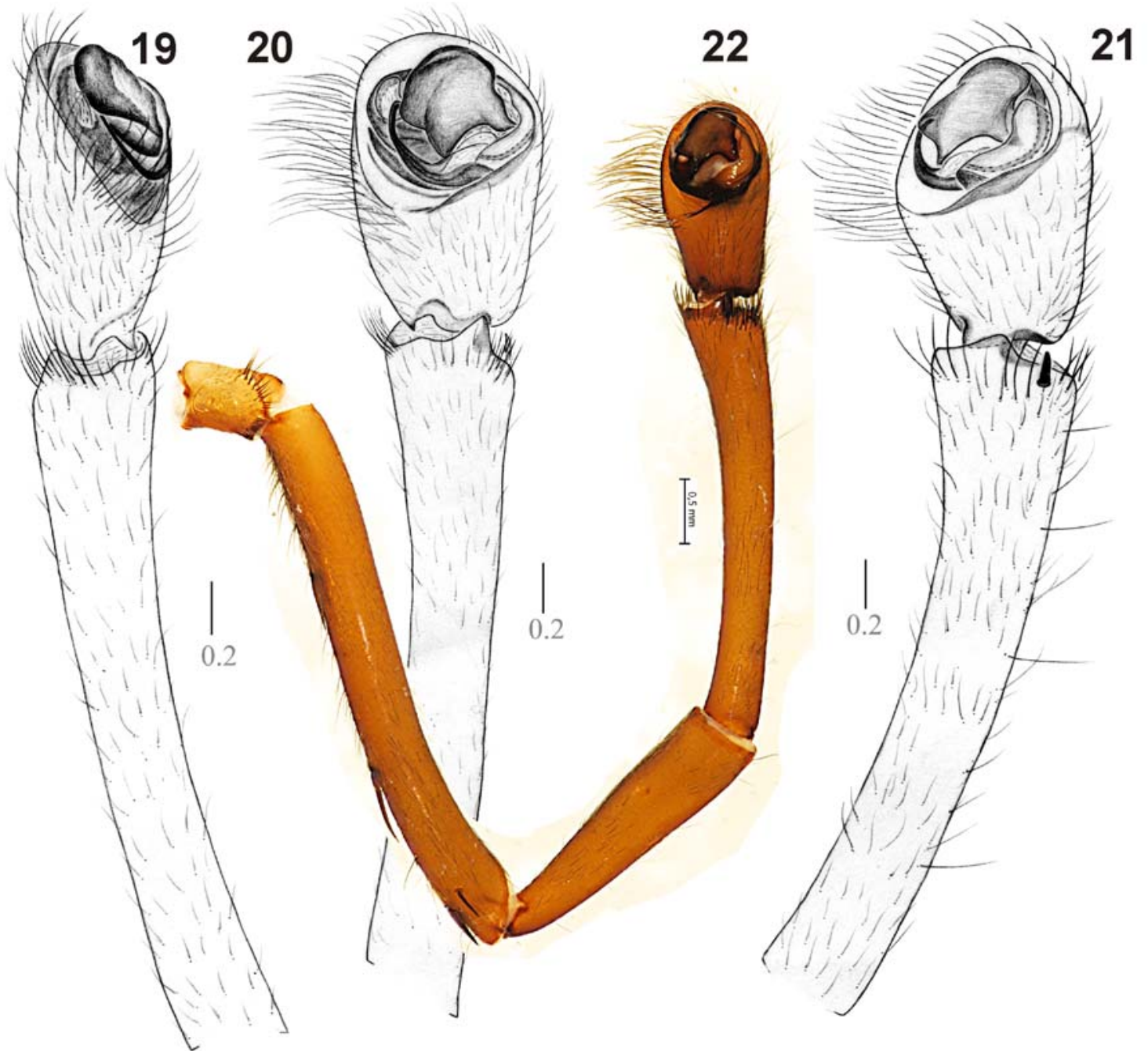

Figs 19-22. Male palp of Sinoctenus zhui sp.n.: 19-21 - tibia and cymbium, prolateral, ventral and retrolateral, respectively; 22 whole palp, ventral.

Рис. 19-22. Пальпа самца Sinoctenus zhui sp.n.: 19-21 — голень и цимбиум, пролатерально, вентрально и ретролатерально, соответственно; 22 - целая пальпа, вентрально.

of ventral spines (counting apical). Spination of legs (apical spines and spines on metatarsi not counted):

\begin{tabular}{|l|c|c|c|c|}
\hline & I & II & III & IV \\
\hline Femur & $3 \mathrm{~d} 4 \mathrm{p} 4 \mathrm{r}$ & $3 \mathrm{~d} 4 \mathrm{p} 4 \mathrm{r} 1 \mathrm{p} 1 \mathrm{r}$ & $3 \mathrm{~d} 4 \mathrm{p} 4 \mathrm{r}$ & $3 \mathrm{~d} 4 \mathrm{p} 4 \mathrm{r}$ \\
\hline Patella & $1 \mathrm{p} 1 \mathrm{r}$ & $1 \mathrm{p} 1 \mathrm{r}$ & $1 \mathrm{p} 1 \mathrm{r}$ & $1 \mathrm{p} 1 \mathrm{r}$ \\
\hline Tibia & $3 \mathrm{~d} 2 \mathrm{p} 2 \mathrm{r}$ & $3 \mathrm{~d} 2 \mathrm{p} 2 \mathrm{r}$ & $2 \mathrm{~d} 2 \mathrm{p} 2 \mathrm{r}$ & $3 \mathrm{~d} 3 \mathrm{p} 2 \mathrm{p}$ \\
& $4-4 \mathrm{v}$ & $4-4 \mathrm{v}$ & $2-2 \mathrm{v}$ & $2-2 \mathrm{v}$ \\
\hline
\end{tabular}

Leg and palpal joints length (specimen 9.3 long): t2

\begin{tabular}{|l|c|c|c|c|c|c|}
\hline & Femur & Patella & Tibia & Metatarsus & Tarsus & Total \\
\hline Palp & 4.30 & 2.30 & 3.25 & - & 1.43 & 11.28 \\
\hline I & 5.25 & 2.50 & 5.0 & 4.80 & 1.75 & 19.30 \\
\hline II & 4.95 & 2.40 & 4.15 & 4.50 & 1.70 & 17.70 \\
\hline III & 4.45 & 2.0 & 3.20 & 4.0 & 1.50 & 15.15 \\
\hline IV & 5.65 & 2.55 & 4.90 & 6.75 & 2.0 & 21.85 \\
\hline
\end{tabular}

Spinnerets yellowish. Posterior lateral spinnerets with elongate apical segment $(A s)$, which is about $1 / 2$ the length of the basal segment (Fig. 7).
Palp as in Figs 9-22. It is longer than the body, its femur 3 times longer than the cymbium, tibia more than 2 times longer than the cymbium; even the patella is longer than the cymbium (Fig. 22). Femur with 3 dorsal, 2 prolateral and 1 retrolateral spines, other sections spineless. Tibia with a small spine-like retrolateral process $(R t)$ (cf. Fig. 21) and a deep retrolateral notch $(R n)$ (cf. Fig. 11), distal (apical) edge of the tibia with a crown of spines and setae (Cs) (cf. Fig. 10). Cymbium gradually widened, widest at distal 1/3; proximal (apical) part rounded, not tapering; basal part as high as bulbus (cf. Figs. 9, 20); prolateral side with a brush of long protruding setae (Sp) (Fig. 10). Bulbus round, strongly embedded into the cymbial fovea $(C f)$, tegulum with a very large and flat median apophysis $(M a)$ almost covering the entire bulbus like a shield (cf. Fig. 9), its inner side with strong ridge $(M r)$ (Fig. 
$18)$; conductor ( $\mathrm{Co}$ ) thick and membranous, located on the prolateral side; embolus (cf. Figs. 14-16) short and thick, with a basal projection $(B p)$ and with a complex tip $(C t)$; embolus originates at about 7 o'clock and terminates at 9:30 o'clock.

DISTRIBUTION. Known only from the Hainan Island, China (Map 1).

ACKNOWLEDGEMENTS. We thank Chao Zhang and Sheng-Tao Guo for collecting the valuable specimens. Special thanks are to Diana Silva for her helpful comments on a draft of the manuscript. English of the earlier draft was kindly checked by Donald J. Buckle (Saskatoon, Canada) and English of the final draft was corrected by Robin Leech. This work was supported in part (to Feng Zhang) by the Ministry of Science and Technology of the People's Republic of China (2006FY110500), by the National Natural Science Foundation of China (Nos. 31093430, 31071885 and 30970325) and by the Russian Foundation for Basic Research grants Nos. 09-04-01365 and 11-04-01716-a.

\section{References}

Brescovit A.D. 1996. Revisão do gênero Centroctenus Mello-Leitão (Araneae, Ctenidae, Cteninae) // Rev. Brasil. Entomol. Vol.40. P.301-313.

Brescovit A.D., Simó M. 2007. On the Brazilian Atlantic Forest species of the spider genus Ctenus Walckenaer, with the description of a neotype for C. dubius Walckenaer (Araneae, Ctenidae, Cteninae) // Bull. Brit. arachnol. Soc. Vol.14. Pt.1. P.1-17.

Gravely F.H. 1931. Some Indian spiders of the families Ctenidae, Sparassidae, Selenopidae and Clubionidae // Rec. Indian $\mathrm{Mu}-$ seum. Vol.33. P.211-282.

Platnick N.I. 2011. The world spider catalog, version 12.0. American Museum of Natural History. On-line at: http:// research.amnh. org/entomology/spiders/catalog/ (Accessed 20 November 2011).

Silva D.D. 2003. Higher-level relationships of the spider family Ctenidae (Araneae: Ctenoidea) // Bull. Amer. Mus.Nat. Hist. Vol.274. P.1-86.

Responsible editor K.G. Mikhailov 